\title{
沖積低地における液状化層トレンチ調査法の提案とその手順
}

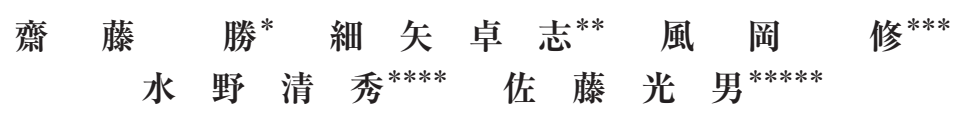

\section{A New Approach and Procedure for Trenching Surveys of Liquefied and Fluidized Strata in an Alluvial Lowland} Masaru SAITO*, Takashi HOSOYA**, Osamu KAZAOKA***, Kiyohide MIZUNO ${ }^{* * * *}$ and Mitsuo SATO ${ }^{* * * * *}$

[Received 13 October, 2016; Accepted 11 January, 2018]

\begin{abstract}
Trenching surveys (excavating a ground surface and observing the exposed strata) are methods for immediately comprehending shallow subsurface stratigraphy, geological structure, and properties of strata. The most suitable survey method is presented for observing liquefied and fluidized strata under the ground, and for considering liquefaction countermeasures in an alluvial lowland where man-made strata are sporadically distributed and the groundwater table is generally shallow. Also presented is an outline of the procedure. To narrow the trench site, it is essential to analyze topographical data, historical record of liquefaction, and subsurface geology based on drilling data and groundwater table. Prior to excavating, sheet piles are driven and tightly arranged around the site. Then, riser pipes and a centrifugal pump are set into the trenching area to lower the groundwater level (the well-point method). During the process of dewatering and discharging water, environmental influences on surrounding areas should be considered. The depth of a trench in practice is 3 to $4 \mathrm{~m}$ or less. If it is necessary to obtain deeper strata, long specimens oriented via special sheet pile tool sampling can be used. After making observations of stratigraphy and structure of normal layers or liquefied and fluidized layers exposed on trench walls, it is useful to make relief peel specimens with a grout material to describe detailed liquefaction and fluidization features. It is proposed that exhibiting peel specimens is effective for understanding liquefaction and fluidization processes. Samples of liquefied strata for some examinations can be collected directly from trench walls.
\end{abstract}

\footnotetext{
* 株式会社ダイヤコンサルタント

***央開発株式会社

****葉県環境研究センター

**** 産業技術総合研究所

****** 伸光エンジニアリング株式会社

* Dia Consultants Co. Ltd., Sendai, 980-0811, Japan

** Chuo Kaihatsu Corporation, Kawaguchi, 332-0035, Japan

*** Research Institute of Environmental Geology, Chiba, 261-0005, Japan

**** National Institute of Advanced Industrial Science and Technology, Tsukuba, 305-8567, Japan

***** Shinko Engineering Co. Ltd., Chiba 260-0834, Japan
} 
Key words : trenching survey, liquefaction, fluidization, alluvial lowland, man-made strata, well-point method, large relief peel method

キーワード：トレンチ調査, 液状化, 流動化, 沖積低地, 人工地層, ウェルポイント工法, 地層の 剥ぎ取り転写

\section{I. はじめに}

大地震に伴って液状化が発生した場所は，噴 砂，陷没および構造物の傾斜などによって，ある 程度把握することが可能である。しかし，どの地 層が液状化したのか，あるいはどのように地層が 流動したのかの特定は, 直接地下の地層を観察し ないとわからない。とくに液状化が起こりやすい 表層部は，人の手による掘り起こしなどで地層の 成層構造が乱されている場合が多く，ボーリング 掘削等による一次元的な調査では，液状化層の分 布が把握しにくい。このような地下の地層の直接 観察には, 溝状に地面を掘削して壁面に液状化し た地層を露出させるトレンチ調査がもっともシン プルでわかりやすい。しかし，地下水面より下位 での液状化層のトレンチ調査の実施例はきわめて 少なく，地震に伴う液状化とこれに引き続く流動 化（風岡ほか, 1994: 以下，この一連の現象を液 状化-流動化と表現する）の実態は明らかとなっ ていない。この実態とそのメカニズムを明らかに することで，正確な液状化-流動化予測とこれに 必要な調査方法の検討や現在提案されているさま ざまな液状化防止方法を地質条件にみあった効果 的なものとするためのデザインの検討が可能とな る。そのためには, 液状化-流動化した地層が直 接観察できるトレンチ調査の事例を増やす必要が ある。

液状化層のトレンチ調査は, 活断層の活動履歴 や断層運動による地層の変形構造などの解明のた めに行われているトレンチ調查手法（例えば, 山 崎ほか, 1984; 岡田, 1990） と基本的には同じで あり, 1983 年日本海中部地震, 1987 年千葉県東 方沖地震，1993 年北海道南西沖地震，1995 年兵 庫県南部地震， 2011 年東北地方太平洋沖地震で 生じた液状化層などに対して実施されている（陶
野, 1986; Nirei et al., 1990; 下川ほか, 1994; 沼田 ほか, 1999; 小松原ほか, 2014 など）。液状化した 地層の研究は, そのほかに遺跡の発掘地点や地 層の自然露出地（露頭）でも多く報告されている (例えば, 堀口, 1986; 寒川, 1992, 1999; 大塚ほか, 1997; 高浜ほか, 1998; 三谷, 2006; 下総台地研究 グループ, 2010 など)。外国での液状化層のトレ ンチ調査や露頭観察も多数ある（例えば, Obermeier, 1996; Bezerra et al., 2005; Reddy et al., 2009; Tuttle et al., 2011; Mugnier et al., 2011)。 これらの研究・報告では, 古地震の履歴や規模の 推定，砂脈や噴砂孔などの液状化一流動化した地 層の形態や粒度組成などに言及されていることが 多いが，特定の地層内で液状化-流動化が部分的 に進行していくような発達過程について述べてい るものは，風岡ほか $(1994,2003)$ などに限られ ている。また，地震時に液状化被害の著しかった 地点と地表に液状化の痕跡が現れなかった地点と の比較のような研究は小松原ほか (2014) で示さ れているのみであり, 液状化予測のためのトレン 于調査研究はほとんどない。さらに，液状化対策 事業に活かすためには, 住宅地などの近傍でトレ ンチ場所を選ぶことが必要になるが，ニュージー ランドの Christchurch でのトレンチ例（Bastin et al., 2016）がある程度で，日本では事例が少な い。これらのほか, 液状化予測のための課題とし て, 液状化-流動化の進行過程の把握に加え, 液 状化しやすい地層の堆積年代や深度効果の影響の 把握, 液状化した地層の強度変化などの解明や液 状化対策の対象とする地域でいかに詳細なデー夕 を提供するかなどがあげられる。

液状化-流動化の進行過程の把握についていえ ば，これまでのトレンチ調査や遺跡や露頭などで の液状化-流動化層の観察例は，ほとんどが地下 水面より上位かあるいはかつては地下水面よりも 
下位であったが隆起して地表に現れたところであ るのに対して, 実際に液状化が発生する地層は地 下水面よりも下位である。液状化-流動化現象が 発生しやすい沖積低地では, 地下水面が高く, そ のため，軟弱な地層でのトレンチ調査では地下水 位を下げるなどの工夫が必要であると同時に，周 囲の環境への配慮が必要になってくる。一般には, 地下水位を低下させ，安定した壁面を露出させる ためには，広大な土地が必要となるほか, 工事の 経費も高くなるため, トレンチ調査は従来液状化 対策事業などではあまり用いられてこなかった。 しかし, 地層の液状化しやすさの評価や液状化対 策事業にトレンチ調査を用いることは今後ますま す重要になってくると考えている。そこで，自治 体などが液状化の実態把握のために行うトレンチ 調查は，安全対策に留意しながら，経費を抑える ために，短時間でコンパクトな掘削調査が有効と 考える。ここでは 2011 年東北地方太平洋沖地震 による液状化が発生した利根川下流地域で行った トレンチ調査例（小松原ほか, 2014）などを経験 として, 地下水位が高い沖積低地での液状化層の トレンチ調査に適した手法を提案し，手順とその 要点をとりまとめた。液状化対策にトレンチ調査 が広く用いられていくことを期待する。

\section{II. トレンチ調査の流れ}

トレンチ調査は以下に示す $(1) \sim(9)$ の流れで 実施する。（1）掘削地点の絞り込み，(2) 事前地 盤調査，（3）トレンチ位置・形状および地下水低 下工規模の決定，（4）地下水位の低下作業，（5） トレンチ掘削作業，（6）観察，（7）地層の剥ぎ取 り転写，（8）サンプリングと試験，（9）総合的な 検討ととりまとめである。

限られた範囲の用地において，短期間内で成果 の上がるトレンチ調査を行うためには，十分な事 前調査を必要とし，掘削場所を絞り込んだうえ で，トレンチ掘削作業は効率的に進めなければな らない。以下の章では, 各手順について概要をま とめる。とくに重要と考えている地下水位の低下 作業と地層の剥ぎ取り転写については, 詳細に記 載する。

\section{III. トレンチ調査の手順とその詳細}

\section{1）掘削地点の絞り込み}

トレンチ調査により, 液状化層の実態を把握す るためには，液状化層や噴砂の分布および地盤状 況などをあらかじめ把握し, 調査に適した用地を 選定する必要がある。このため, 液状化跡の分布 調査, 既存資料による地盤状況確認, 候補地現況 確認などを実施し，トレンチ調査地点の絞り込み を行う。

\section{1-1）液状化跡の分布調査}

トレンチを掘削し壁面に液状化跡を露出させる ためには，噴砂孔や地割れなど流動した物質の地 表への出口を確認し，その直下を掘削するのが もっとも可能性が高い選択肢である。しかし，噴 砂跡は, 浸食作用を受け形状が変化するとともに, 道路，公園などの公共用地や住宅地，耕作地など の復旧に伴い，地表に堆積した砂が除去され，整 地が行われて失われていく。このため, 地震発生 後速やかに噴砂孔や地割れの位置・形状や，地表 に堆積した砂の分布や厚さを記録しておくことは, 液状化層のトレンチ掘削位置の決定のために重要 となる。また，過去の地震で生じた液状化跡の分 布を報告した文献をもとに，液状化が生じた地点 を確認する。満足な文献がない場合は，地震直後 の空中写真や現地写真の判読, 周辺住民への聞き とり調査等により, 液状化したと推定される地点 を把握する。液状化した地点あるいは液状化した と推定される地点から, 液状化した確からしさを 考慮してトレンチ調查の候補地を絞り込む。液状 化した地点が不明確な場合は，後述する既存資料 による地盤状況確認に基づき, 液状化しやすい地 層が存在していること，あるいはその地層が分布 すると予想される地形であることを確認して候補 地を絞り込む。

\section{1-2）既存資料による地盤状況確認}

収集する資料は, 空中写真, 古地図, 地質図, 土地条件図, 治水地形分類図, ボーリング調查結 果, 過去の地震被害状況, 地形改変の履歴に関す る資料などである。これらの既存資料をもとに候 補地または候補地になりえる地点の地盤状況を確 
認する。確認事項は，地形区分，構成地層，地下 水位, 地形改変の有無などである。液状化しやす い地層が堆積している場所としては，後背湿地， 旧河道, 旧池沼, 谷底低地, 浜堤間低地, 三角州, 海岸低地，砂州，埋立地などがあげられる。地形 改変の把握に関しては，地元住民の聞きとり調査 も有効である。液状化しやすい地質は，水に飽和 したゆるい砂層であり，そのような条件を満たす 調査地を選定するため，地下水位の分布や砂層の 締まり具合に関する既存資料を検討することが重 要である。

\section{1-3）候補地現況確認}

絞り込んだトレンチ候補地については，実際に 掘削工事が可能かどうかを判断するために，周辺 の地形や構造物の状況, 遺跡の指定地など法律で 規制された範囲かどうかを確認する。確認事項の 詳細を以下に示す。

(1)用地の広さ：トレンチ掘削範囲，掘削土砂仮置 き場抒よび作業スペースが確保できるか否か。

(2)搬入路：重機の通行に十分な幅があるか否か や，支障となる架空線の有無など。

(3)用地の利用状況：トレンチ掘削の支障となる立 木や耕作物の有無，耕作の予定など。

(4)水利状況 : 後述するトレンチ壁面安定化のため の地下水低下作業を行う場合に影響が及ぶ可能 性のある水源の有無やその揚水を流す水路の有 無。

(5)埋設物：トレンチ掘削の支障となる上・下水道 管，ガス管，通信ケーブル，暗渠などの埋設物 の有無。

(6)地権者・管理者と規制範囲：掘削許可が得られ るかどうか，法律にしたがい，申請が必要かど うか。

上記(4)において，周辺に利用水源がある場合は あらかじめ影響を評価し，地権者などと協議して 調査実施計画を立てる必要がある。水源には，井 戸，河川，ため池および湧水がある。確認事項は， 水源の位置，種類，利用目的，利用頻度，利用量 などであり，水源が井戸であるならば，深度，水 位，口径などの井戸構造，動力の有無，現地水質

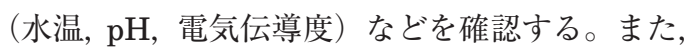

ウェルポイント工（ストレナー付吸水装置をパイ プ先端にとりつけ，ポンプで強力に地下水を吸引 し排水することで，地下水位を低下させる工法） による揚水を水路などに放流する場合も，水の利 用者と協議し調查実施計画を立てる必要がある。 なお，水質分析は，後述するボーリング調査に伴 い採取した地下水を用いるほうがよい。

以上の確認をもとにトレンチ調査に適した箇所 を選定する。

\section{2）事前地盤調査}

トレンチを掘削する正確な位置や規模を計画し 地下水低下工の仕様を決めるため，事前の地盤調 査を行う。地盤調查では，ボーリング調查，地下 水の水位測定と水質分析などを実施する。なお, 既存資料から，地下の地質状沉や水質などが明ら かな場合は，ボーリング調査や地下水の分析を省 略してもよい。

\section{2-1）ボーリング調査}

液状化トレンチでは噴砂の供給源の地層まで掘 削することが多いことから，トレンチ掘削前にオー ルコアボーリングとサウンディング試験によって 地質層序や地層の締まり具合を把握し，トレンチ 掘削計画を立てるとよい。ボーリング調査の項目 としては，オールコアボーリング，標準貫入試験 やスウェーデン式サウンディング試験ないし簡易 連続貫入試験，地下水位測定，ウェルポイントを 施す帯水層の地下水位観測井設置があげられる。

\section{2-1.1) オールコアボーリング}

オールコアボーリングは，液状化の可能性のあ る地層や帯水層, 難透水層の詳細な層序の把握が 目的である。そのため，採取率がよいこと，コア が乱れていないことが必要である。掘削時の振動 で液状化が生じることも避ける必要がある。この ため，ボーリングはスリーブを内蔵した外径 86 $\mathrm{mm}$ または $66 \mathrm{~mm}$ のロータリー式スリーブ内蔵 二重管サンプラー（JGS 1224-2003）を使用する ことが望ましく，コアを慎重に採取する必要があ る。

2-1.2）標準貫入試験，スウェーデン式サウン ディング試験，簡易連続貫入試験

トレンチ予定箇所周辺の地層断面を作成するた 
めには，周辺の既存ボーリングとの対比が必要で ある。既存ボーリングと対比するためには，標準 貫入試験（JIS A 1219）の試験值を入れたボー リング柱状図が有効である。また，コアの対比の 参考にする場合や，室内試験試料として使用する 場合もあるので，標準貫入試験用サンプラー中の 試料は，地層ごとに分けて試料ビンまたはビニー ル袋に収納する。なお，その際，ボーリング孔名 と採取深度を試料ビンまたはビニール袋に明示す る。

標準貫入試験は，通常，深度 $1 \mathrm{~m}$ ごとに 1 回， $N$ 值（地盤強度の指標）を測定しているので, 必要に応じ，スウェーデン式サウンディング試験 （JIS A 1221）や簡易連続貫入試験（JGS 1433） などを併用して，地盤強度に関する情報を補完 し, 液状化-流動化部分の検討材料とする（風岡 ほか, 2000, 2002)。

\section{2-1.3）地下水位測定}

地下水位は自然水位と日々のボーリング作業開 始前の水位を水位計を用いて測定する。ボーリン グ掘削の進渉と水位の変化をグラフに表すと, ボーリング掘削過程における水位上昇の有無によ り被圧带水層の有無が把握できることがある。被 圧帯水層は，確実な遮水を必要とするため，その 存在を把握することが重要となる。なお観測され る水位は，裸孔区間におけるすべての透水層の水 位がバランスした水位と考えられる。

\section{2-1.4) 地下水位観測井設置}

地下水低下工の効果を判定するため，ボーリン グ掘削後に塩ビ管を挿入し，地下水位観測井を設 置する。また，ボーリング掘削後の地下水位の変 化を把握するために，トレンチ掘削までの間，地 下水位を定期的に観測するとよい。また，事後の 液状化予防対策のため，この観測井を利用して現 場透水試験を行い，帯水層ごとの透水係数を求め るとよい。

\section{2-2）地下水の水質分析}

地下水位低下作業により水路などに排水した地 下水は，水田などの耕作に利用されることが考え られる。また，河川・池などの生態系に影響を及 ぼす可能性もある。このため, 排水する地下水が
国の定める排水基準や環境基準を満たしているの かを，水質分析を行って事前に検証する必要があ る。地下水は，設置した観測井から採水するのが よい。また，ハンドオーガーボーリング，ダブル スコップ等により地盤を削孔して，ベーラー等の 採水器を用いて採水できる場合もある。

\section{3) トレンチ位置・形状および地下水低下工規 模の決定}

\section{3-1）トレンチ位置の決定}

トレンチ候補地が液状化しやすい地層が分布す る地形に確実に立地していること，現地確認調査 や水質分析で確認した事項がトレンチ掘削の支障 とならないこと，および可能な掘削範囲内に液状 化層の出現が期待できることなどの条件に基づ き，トレンチ位置を決定する。

\section{3-2）トレンチ形状の決定}

\section{3-2.1） トレンチの向きの決め方}

砂脈など液状化した地層の流動構造は，壁面が できるだけ地表で観察される砂脈の延びと直交す る向きのほうが観察しやすいことから，そのよう な向きにトレンチを配置する。砂脈の位置が不明 確な場合は，帯状に表土や噴砂後の人工擋乱層を すきとり，砂脈の位置を特定すると，トレンチの 配置を決めやすい。ただし，砂脈が垂直に延びて いるとは限らないし，派生した砂脈が主脈と平行 になるとは限らないので, 観察したい液状化層の 出現状況にあわせて，トレンチ掘削時に形状を微 修正する。

\section{3-2.2) トレンチの深さの決め方}

トレンチ調査におけるトレンチの哚さは，安全 性や後述する揚水能力を考えた場合に，3〜 $4 \mathrm{~m}$ 以内が適切なサイズである。利根川下流域などの 沖積低地の地下水面は, 盛り土が薄い場合には, おおむね地表下数 $10 \mathrm{~cm}$ から $1.5 \mathrm{~m}$ 程度までの ところにあり，それより下位の砂層は液状化判定 の対象層となる。利根川下流地域で事前のボーリ ング調査から浚渫砂層主体の人工地層の厚さが $5 \mathrm{~m}$ 程度あると推定された場所で, 深度 $3 \mathrm{~m}$ ま でのトレンチ掘削を行ったが，液状化発生層はほ ぼ壁面内でとらえることができた（小松原ほか， 2014）。しかし，最新の地震によって形成された 
砂脈や液状化した地層がさらに深部にまで及ぶも のもありえる。液状化がどの深度まで及んでいる のかを解明するためには，トレンチをさらに深く 掘るか，ボーリング調査あるいは地層抜き取り装 置を用いた調査を実施する必要がある。トレンチ を深く掘る場合は，地下水低下工の規模を拡大 し，トレンチに小段を設け二段掘りにするなどの 処置が必要である。地層抜き取り装置は定方位で かつボーリング径よりも幅広く地層を採取できる 利点がある一方，一般的にはかなり大がかりにな る。また，ボーリング調査と同様に振動により地 層が液状化を起こす可能性がある。地層抜き取り 装置を用いた具体的な方法や調査結果などについ ては，例えば，原口ほか（1998），Takada and Atwater (2004)，重野ほか（2015）に記されて いる。

\section{3-2.3） トレンチ法面の傾斜角とトレンチの広 さの決め方}

トレンチ調査の壁面はおもに未固結な地層から 構成されるため, トレンチ法面の傾斜は一般にゆ るくする。掘削深度を $3 \mathrm{~m}$, トレンチ底面の広さ を $4 \mathrm{~m} \times 2 \mathrm{~m}$ ，掘削法面の傾斜角を 45 度とした

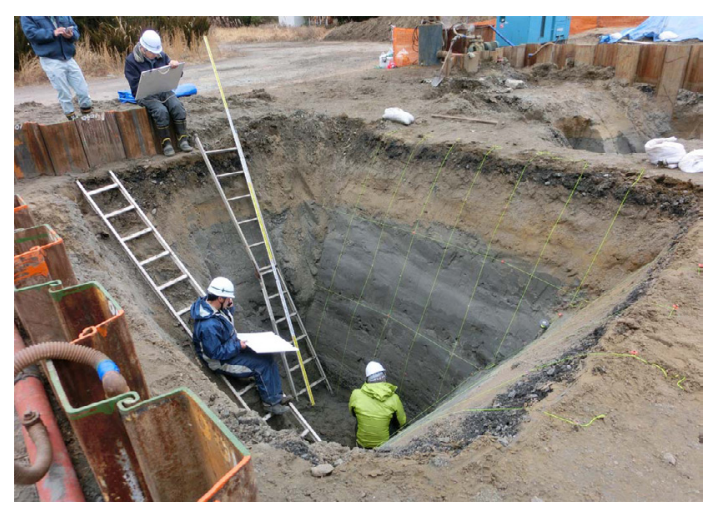

図 1 トレンチ掘削例 (千葉県香取市). 縦方向の水糸 の間隔は $50 \mathrm{~cm}$, 水平方向の水糸は $1 \mathrm{~m}$ 間隔. 正 面の壁面の傾斜は 60 度程度でも，シルト層が挟 まっているため，安定している。

Fig. 1 View of trench walls (Katori, Chiba Prefecture). The interval between vertical lines is $50 \mathrm{~cm}$ and that between horizontal lines is $1 \mathrm{~m}$. The front wall with a slope angle of approximately $60^{\circ}$ is stable because of interbedded silty layers.
場合，トレンチ上面の広さは $8 \mathrm{~m} \times 10 \mathrm{~m}$ となる。 構成層がゆるい砂層のみからなる場合には，さら に法面傾斜はゆるくする必要があるため，面積は さらに広くなる。掘削した土砂置き場や重機の作 業範囲を考慮すると，最低 $20 \mathrm{~m} \times 20 \mathrm{~m}$ 程度の 用地を必要とする。ただし, 壁面構成層にシルト 層などの細粒層が含まれている場合には，地下水 位を低下させた後の法面は，60 度程度の傾斜角 でも安定していることもあり，必要な用地の面積 を狭くすることも可能である（図 1 ）。

\section{3-2.4）その他の工夫}

トレンチの片面だけを観察面とし，もう片方側 は土囊などを積んで掘削土砂の置き場とすること や，砂脈沿いに限定した小さなトレンチを複数掘 ることによって，借用する用地の面積を減らす工 夫もできる（図 2 )。こうしたトレンチ形状の軽 微な変更は，掘削作業を行いながら判断すること が多い。また，砂脈や噴砂孔など地表近くの液状 化一流動化跡だけを観察する目的であれば，地下 水面に達したところで掘削を打ち止めてコンパク

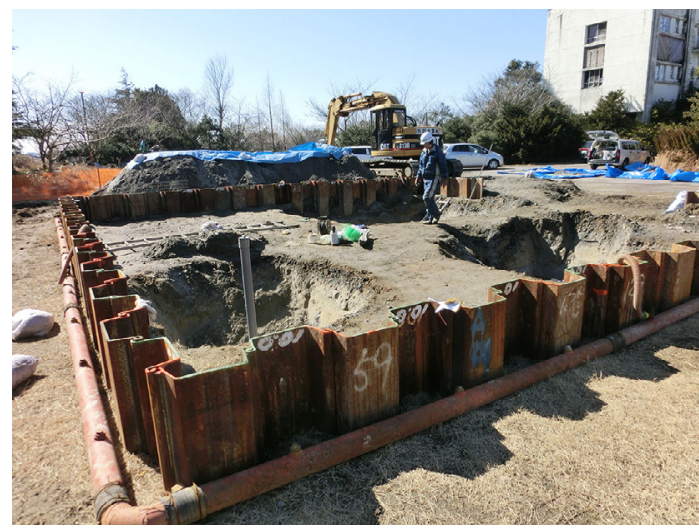

図 2 シートパイル，ウェルポイント工法のライザー パイプやヘッダーパイプ, 複数の小規模なトレ ンチ掘削と，ボーリング・地下水位観測井およ びブルーシートで覆った掘削土砂の配置例（千 葉県香取市).

Fig. 2 Overview of trench site showing small trenches and a borehole pipe (groundwater observation well) enclosed by sheet piles, riser, and header pipes used for the well-point method, and excavated soil covered by blue sheets (Katori, Chiba Prefecture). 
トなトレンチにすることもありうる（図 3 ）。

\section{3-3）地下水位低下工規模の決定}

現地でのボーリング調査と地下水位観察結果か ら判断されるシルト層などの不透水層や液状化す る可能性の高い砂層の深度分布，粒度および締ま り具合から，トレンチの形状を考慮して，トレン 于底面以下まで地下水位を低下させられる排水能 力を見積り，それにみあった地下水低下工の仕様 を決める。詳細は次項に記載する。地下水面に達 しない浅いトレンチの場合には，この工法は不要 である。

\section{4）地下水位の低下作業}

地下水位を低下させる工法として, 浅い深度の 水を効率よく排水できる「ウェルポイント工法」 が有効である。ウェルポイントを設置する際，シー トパイル（矢板，遮水板）の打ち込みを行うとよ り効率的に地下水位を低下させることができる。

\section{4-1）シートパイルの打ち込み}

トレンチ位置の決定後，縮尺 200 分の 1 程度 の平面図および断面図に，砂脈の位置，トレンチ 形状㧍よびシートパイルの打設位置を示す。決め られた調査範囲内にシートパイルを隙間なく打ち 込み，地下水の側方からの流入を遮断する。ま

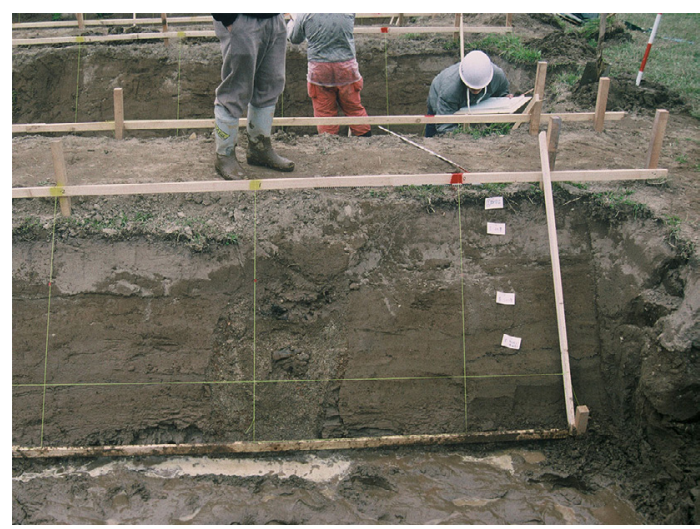

図 3 自然地下水面までの浅いトレンチ調査の例（北 海道せたな町)。報告は下川ほか（1994）に示さ れている. 水糸の間隔は $1 \mathrm{~m}$.

Fig. 3 Example of shallow trench excavated to groundwater level (Setana, Hokkaido), reported by Shimokawa et al. (1994). The interval between lines is $1 \mathrm{~m}$.
た，下方からの地下水の侵入を防ぐためには，遮 水に十分な効果がある厚さのシルト・粘土層まで シートパイルを打ち込む必要がある。ただし，通 常，使用するシートパイルは長さ $10 \mathrm{~m}$ 程度まで であり，10 mが深度の限界となる。シートパイ ルはラフタークレーンとバイブレーターにより打 ち込む。

なお，シートパイルの根入れ長さは(1)式およ び $(2)$ 式により求める（日本道路協会, 1999）。

$$
\begin{aligned}
& D=\frac{\text { 安全係数 }}{\beta} \\
& \beta=\sqrt[4]{\frac{k H \cdot B}{4 E I \alpha}}
\end{aligned}
$$

ここで $D=$ 根入れ長さ， $\beta=$ 特性值であり，安 全係数は 3 以上が理想とされるが，実用的に 2.5 を採用する（日本道路協会, 1999)。Bは土留 め壁の幅でシートパイルの単位幅 $1 \mathrm{~m}$ とする。 $E$ はシートパイルのヤング係数で $2.000 \times 10^{8}$ $\left(\mathrm{kN} / \mathrm{m}^{2}\right), I$ はシートパイルの断面二次モーメン トで $0.000168\left(\mathrm{~m}^{4}\right) ， \alpha$ は根入れ計算用の有効率 で 1.000 とする。 $k H$ は水平方向地盤反力係数と 呼ばれ，地層とトレンチ条件によって変わるため 複雑であり（日本道路協会, 1999），詳細は省略 する。

シートパイルの打ち込み深度検討断面図を図 4 に示す。 $4 \mathrm{~m}$ の深度のトレンチを掘削し，壁面の 傾斜を $49^{\circ}$ とした場合の検討例を示す。最初に, 受働崩壊線の角度を $45^{\circ}$ とした場合の仮想地盤面 を算出する $(\mathrm{GL}-1.33 \mathrm{~m}$ ：図 4$)$ 。この場合, $k H=3475\left(\mathrm{kN} / \mathrm{m}^{3}\right), \beta=0.4008\left(\mathrm{~m}^{-1}\right)$ となり, 仮想地盤面からの根入れ長さ $(D)$ は $6.24 \mathrm{~m}$ と 計算される。GL からの根入れ長は $6.24+1.33$ $=7.57 \mathrm{~m}$ となる。ここでシートパイルは $50 \mathrm{~cm}$ 刻みの製品となるため, GL からのシートパイル 長は $8.00 \mathrm{~m}$ となり, $50 \mathrm{~cm}$ の頭出しの長さを加 えると $8.50 \mathrm{~m}$ が必要長と計算される。トレンチ 壁面の傾斜が多少変化しても，シートパイルの長 さはそれほど変化しない。

\section{4-2）ウェルポイントの設置}

ウェルポイント工法は，通常の揚水に使用され 


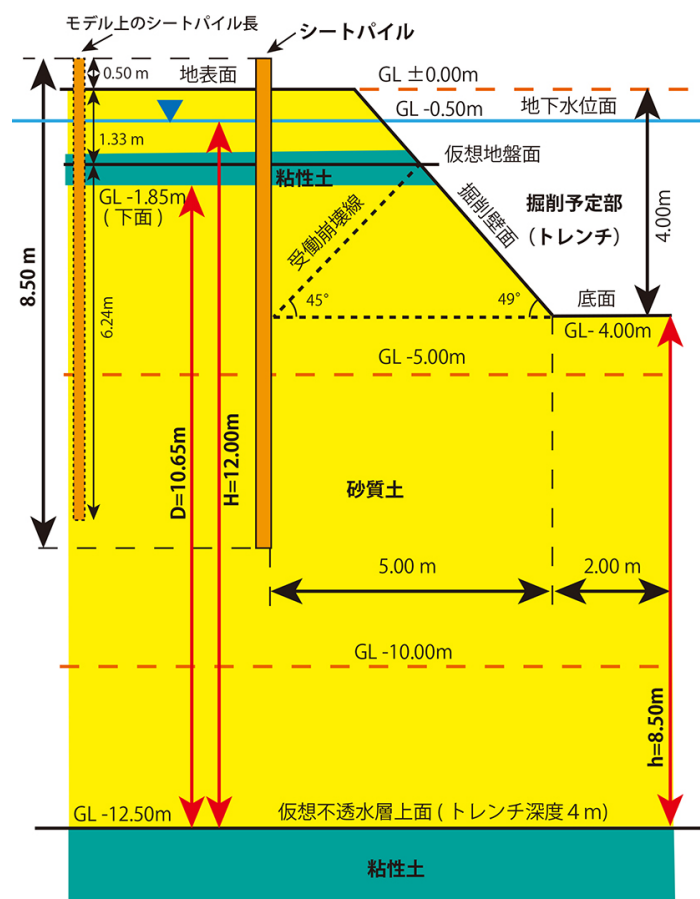

図 4 シートパイルの根入れ長さと揚水量を計算する ための地下地質モデル.

Fig. 4 A subsurface geological model for calculating the lengths of sheet piles and pumping discharge.
るサクションポンプを真空ポンプに置き換え，強 制的に汲み上げる原理であり，浅層の地下水を効 率的に排水することができる（ウェルポイント協 会, 2007 ：図 5 )。具体的には以下のように設置 を行う。

最初に，揚水管（以下，「ライザーパイプ」と 記す）の先端部（ウェルポイント）を設定深度に 設置するための作業を行う。呼び水を用意してお き，水圧をかけながらライザーパイプに注水し， 地盤に孔を開けてライザーパイプを地中に押し込 む。押し込む際に生じたライザーパイプと孔壁の 隙間にフィルター材としてケイ砂を投入する。ラ イザーパイプは空気を吸うと機能しなくなる恐れ があるので，地下水面より十分深い深度にライザー パイプの先端が来るように設置する。また，異な る深度に交互にヒューガルポンプ（渦巻き型排水 ポンプ）を設置する場合がある。これにより，浅 層部の地下水位を短時間に下げ，さらに深層部の 地下水位を下げることができるメリットがある。 トレンチの大きさにあわせて配管の本数および長 さを決定し，ヒューガルポンプおよびノッチタン クの準備を行う。宙水を排水する必要がある場合 は，宙水排水用にライザーパイプを設置する。次 に，ライザーパイプと地上との交差部にヘッダー

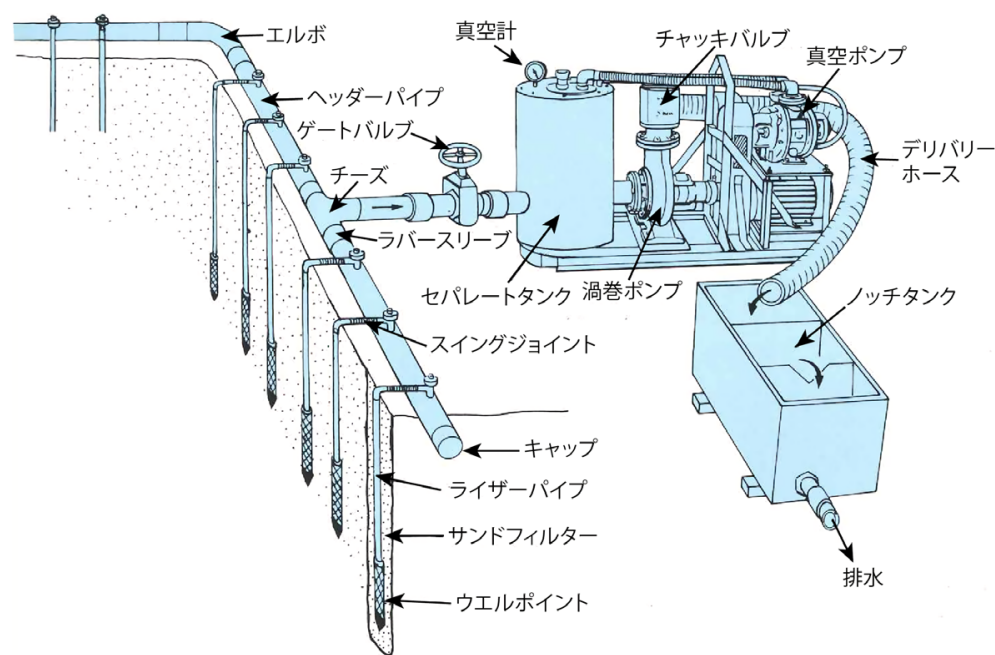

図 5 ウェルポイント・排水機構配置図（日本建設機械商事株式会社提供）.

Fig. 5 Illustration of well-point groundwater extraction system provided by Nihon Kensetsu Kikai Shoji Co. Ltd. 
パイプと呼ばれる集水管を接続し，揚水した水が ヒューガルポンプを通じてノッチタンクに排水で きるようにする。ノッチタンクの水は必要に応じ て排水施設に誘導する。

\section{4-3）揚水量の算出とウェルポイントの本数}

掘削予定のトレンチ形状を入れた地質断面図 （図 4 ）と推定される水理定数をもとに，(3) 式よ り地下水位を低下させた際の揚水量を算出する。 次に（4)式により揚水量に応じたウェルポイン ト（ライザーパイプ）の本数を求める。ここで 用いる(3)式および $(4)$ 式はいずれも地盤工学会 （1991）による。

$$
Q=\frac{2 \pi D k(H-h)}{\ln \left(R / r_{0}\right)} \beta
$$

ここで, $Q$ : 揚水量 $\left(\mathrm{m}^{3} / \mathrm{min}\right), k$ : 透水係数 $(\mathrm{m} / \mathrm{min}), D$ : 带水層の厚さ $(\mathrm{m}), R$ : 影響圈半 径 $(\mathrm{m}), r_{0}$ : 仮想井戸半径 $(\mathrm{m}), H$ : 影響半径 $R$ の位置の水位高さ $(\mathrm{m}), h$ : 仮想井戸半径 $r_{0}$ の位置の水位高さ $(\mathrm{m}), \beta$ : 係数 $\beta=1.0$ であ る。

$$
n=\frac{(2 \sim 3) Q}{q w^{\prime}}
$$

ここで, $n$ : ウェルポイントの本数, $Q$ : 定常状 態の揚水量 $\left(\mathrm{m}^{3} / \mathrm{min}\right), q w^{\prime}$ : ウェルポイント 1
本あたりの揚水能力 $\left(\mathrm{m}^{3} / \mathrm{min}\right)$ である。

\section{4-3.1）揚水量 $\boldsymbol{Q}$ の算出例}

揚水量 $Q$ の算出例を表 1 に示す。ここでは, ボーリング調査または既存の資料から，掘削計 画箇所の自然地下水位を $\mathrm{GL}-0.5 \mathrm{~m}$ とし, GL $-0.85 \sim-1.85 \mathrm{~m}$ とトレンチの深度の 3 倍の 深さ以深には粘性土があり，それ以外は砂質土 とした。トレンチの深度を $3 \mathrm{~m}$ と $4 \mathrm{~m}$ とした 場合をそれぞれ想定し（図 4 は $4 \mathrm{~m}$ の場合）, 各值を設定した $(\mathrm{GL}-12.5 \mathrm{~m}$ の不透水層から の高さで示す)。影響圈半径 $R$ を $100.0 \mathrm{~m}$ と 仮定し，仮想井戸半径 $r_{0}$ は，トレンチ形状を $10 \mathrm{~m} \times 16 \mathrm{~m}$ ，深度 $3 \mathrm{~m}$ とした場合，それを円 形で近似して半径を $8.28 \mathrm{~m}$ とし，トレンチの形 状を $12 \mathrm{~m} \times 18 \mathrm{~m}$, 深度 $4 \mathrm{~m}$ とした場合は半径 $9.55 \mathrm{~m}$ とした。透水係数 $k$ は, いくつかの求め 方があるが，ここでは地下水面より下の地層の $D_{20}$ 值 $(20 \%$ 粒径 $(\mathrm{mm}))$ と透水係数の関係表 （土質工学会, 1987）により算出した。 $D_{20}$ は通常 土質試験の粒度試験結果から得られるが，土質試 験を実施していない場合は，土質分類より近似的 に求めることも可能であり，表 1 では土質が極 細粒砂から粗粒砂の場合の值と，それにほぼ対応 する透水係数の值（土質工学会, 1987）を示し, トレンチ掘削深度 $3 \mathrm{~m}$ と $4 \mathrm{~m}$ ごとに，計算され る排水量 (揚水量) を示した。

表 1 粒径 $\left(D_{20}\right)$ と透水係数, 必要揚水量, ウェルポイントの排水能力およびウェルポイントの本数との関係.

Table 1 Relations among grain diameter $\left(D_{20}\right)$, permeability coefficient, pumping discharge, pumping capacity of well-

\begin{tabular}{|c|c|c|c|c|c|c|c|}
\hline $\begin{array}{c}\text { トレンチ } \\
\text { 深度 } \\
(\mathrm{m})\end{array}$ & 土質区分 & $\begin{array}{c}D_{20} \\
(\mathrm{~mm})\end{array}$ & $\begin{array}{l}\text { 透水係数 } \\
k(\mathrm{~cm} / \mathrm{s})\end{array}$ & $\begin{array}{c}\text { 必要排水 } \\
\text { (揚水) 量 } \\
Q\left(\mathrm{~m}^{3} / \mathrm{min}\right)\end{array}$ & $\begin{array}{l}\text { ウェル } \\
1 \text { 本当 } \\
\text { 揚才 } \\
q w^{\prime}(\end{array}$ & $\begin{array}{l}\text { ポイント } \\
\text { 当たりの } \\
\text { 水能力 } \\
\left(\mathrm{m}^{3} / \mathrm{min}\right)\end{array}$ & $\begin{array}{c}\text { ウェルポイント } \\
\text { 本数 (参考) }\end{array}$ \\
\hline \multirow{4}{*}{3} & 極細粒砂 & $0.06 \sim 0.10$ & $4.60 \times 10^{-4} \sim 1.75 \times 10^{-3}$ & $0.0142 \sim 0.0540$ & & $\sim 0.0013$ & $22 \sim 84$ \\
\hline & 細粒砂 & $0.12 \sim 0.25$ & $2.60 \times 10^{-3} \sim 1.40 \times 10^{-2}$ & $0.0802 \sim 0.4318$ & 0.0026 & $\sim 0.025$ & $12 \sim 63$ \\
\hline & 中粒砂 & $0.30 \sim 0.50$ & $2.20 \times 10^{-2} \sim 7.50 \times 10^{-2}$ & $0.6786 \sim 2.3134$ & 0.002 & $\sim 0.065$ & $41 \sim 139$ \\
\hline & 粗粒砂 & $0.60 \sim 1.00$ & $1.10 \times 10^{-1} \sim 3.60 \times 10^{-1}$ & $3.3929 \sim 11.1047$ & 0.07 & $\sim$ & $97 \sim 318$ \\
\hline & 極細粒砂 & $0.06 \sim 0.10$ & $4.60 \times 10^{-4} \sim 1.75 \times 10^{-3}$ & $0.0275 \sim 0.1048$ & & $\sim 0.0013$ & $43 \sim 162$ \\
\hline & 細粒砂 & $0.12 \sim 0.25$ & $2.60 \times 10^{-3} \sim 1.40 \times 10^{-2}$ & $0.1557 \sim 0.8382$ & 0.0026 & $\sim 0.025$ & $23 \sim 122$ \\
\hline & 中粒砂 & $0.30 \sim 0.50$ & $2.20 \times 10^{-2} \sim 7.50 \times 10^{-2}$ & $1.3171 \sim 4.4902$ & 0.002 & $\sim 0.065$ & $79 \sim 269$ \\
\hline & 粗粒砂 & $0.60 \sim 1.00$ & $1.10 \times 10^{-1} \sim 3.60 \times 10^{-1}$ & $6.5856 \sim 21.5528$ & 0.07 & $\sim$ & $189 \sim 616$ \\
\hline
\end{tabular}
point, and number of well-points. 


\section{4-3.2) ウェルポイントの揚水量}

与えられた透水係数から, ウェルポイント 1 本 あたりの揚水量のレンジを, 地盤工学会 (1991) の図から読みとることができる。さまざまな透水 係数に対応したウェルポイント 1 本あたりの揚 水能力のレンジを表 1 にまとめた。ただし，透 水係数の值はそれほど正確に求められるものでは なく，あくまでも目安にすぎない。

\section{4-3.3) ウェルポイントの本数}

式(4)に基づき, 必要なウェルポイントの本数 を表 1 に示した。透水係数やそれから見積もら れるウェルポイント 1 本あたりの揚水能力は正 確な值ではないため, 本数にかなり幅があるが, それが 100 本を超えるような場合は，設定した 広さのトレンチでは現実的ではない。すなわち， 透水係数の高いおもに粗粒砂層ないしはそれより 粗い地層では, トレンチの深度は $3 \sim 4 \mathrm{~m}$ 程度 までが揚水能力の限界であると考えられる。

\section{4-4）トレンチとウェルポイント配置の実例}

利根川下流域で実施した際の工事仕様例を表 2 に示す。

トレンチの形状を $10 \mathrm{~m} \times 16 \mathrm{~m}$, 掘削深度 $3 \mathrm{~m}$ とした。構成される地層は, 細粒砂層〜中粒砂 層が主体であり, $D_{20}=0.18 \mathrm{~mm}$ として透水係数 $k=6.85 \times 10^{-3} \mathrm{~cm} / \mathrm{s}$ を採用し, 必要排水量 $Q=$ $0.211 \mathrm{~m}^{3} / \mathrm{min}$, ウェルポイント 1 本あたりの揚 水能力 $q w^{\prime}$ を最大 $0.01 \mathrm{~m}^{3} / \mathrm{min}$, ウェルポイント の必要数を最低 42 本と見積もった。ウェルポイ ントを $10 \mathrm{~m} \times 16 \mathrm{~m}$ の長方形に配置する場合に は，約 $1.2 \mathrm{~m}$ 間隔となる。

\section{5) トレンチ掘削作業}

\section{5-1）トレンチの掘削・埋戻し作業}

\section{5-1.1) 重機搬入}

調査箇所が重機搬入の可能な道路から離れてい る場合は, 搬入路を整備する。必要に応じ整地と 伐採を行い，水田や湿地などの軟弱な地盤の場合 は, 敷鉄板やポリエチレン製敷板を用いてトラフィ カビリティ（車両の通行に耐えうる土の能力）を 確保する。

\section{5-1.2）掘削}

掘削は基本的に油圧ショベルで行う。油圧ショ
表 2 ウェルポイント工仕様例.

Table 2 Example of numerical data used for well-point method works.

\begin{tabular}{cc}
\hline 項目 & 数量 \\
\hline トレンチの外形 & $10.0 \mathrm{~m} \times 16.0 \mathrm{~m}$ 長方形 \\
トレンチの深度 & $3 \mathrm{~m}$ \\
ウェルポイント本数 & 42 本 \\
ウェルポイント間隔 & $1.20 \mathrm{~m}$ \\
ライザー長 & $3.60 \mathrm{~m} \sim 5.50 \mathrm{~m}$ \\
プラントポンプ台数 & 1 セット \\
運転期間 & 10 日 \\
水中ポンプ能力 & $5.5 \mathrm{kw}$ \\
バキュウムポンプ能力 & $7.5 \mathrm{kw}$ \\
プラント数 & 1 セット \\
排水量 $(\boldsymbol{Q})$ & $0.211 \mathrm{~m}^{3} / \mathrm{min}$ \\
\hline
\end{tabular}

ベルは，掘削する土量，深さによって適宜大きさ を選択する。最初に人力で表土を帯状にすきとり， 液状化跡や砂脈の位置を確認し，トレンチの掘削 形状を微修正する。次に, トレンチの中央付近を 油圧ショベルで掘削し, 液状化した地層を確認し 掘削深度を確定する。また，必要に応じ計画形状 を変更する。油圧ショベルにより計画された形状 になるよう掘削し掘削面を荒仕上げした後，ねじ り鎌や立て鎌を用い，人力で壁面を整形する。な お，時間がとれる場合は，一気に深部まで掘削せ ず，遺跡発掘調查を行うように順次，層ごとに砂 脈や地層の変形を観察するとより詳細な液状化一 流動化に伴う現象を確認できる。壁面整形時に発 生する残土は, トレンチ底を埋めてトレンチの深 度を浅くしてしまうため, ベルトコンベアーを用 意し，残土をトレンチの外へ搬出するとよい。ま た，壁面に蛍光色の水糸で $1 \mathrm{~m}$ グリッドの縦糸 と横糸を設置する。

\section{5-1.3）安全対策}

人が近づく可能性がある場所は，バリケード， ネット，トラロープなどでとり囲み，調査範囲を 明示するとともに，夜間は点滅燈で不用意に人が 立ち入らないような対策を行う。

また，夜間にポンプの吸水音が問題となる場合は, ポンプをなるべく住宅から離した場所に設置し, ポンプを覆う防音施設を施すなどの対策を行う。 


\section{5-1.4）トレンチ維持期間}

トレンチの壁面を多くの人に観察してもらう場 合には，トレンチ維持期間を長めに設定する必要 がある。一方，周囲の環境への影響や経費削減の ため，地下水汲み上げ（地下水低下）の期間をで きるだけ短縮したい場合には，トレンチ掘削開始 から埋戻しまでを 1 週間程度で済ませることも 可能である。地下水面まで達しない深度の簡易卜 レンチの場合には, トレンチの掘削開始から，後 述する地層の剥ぎ取り転写（仕上げを除く）を含 め, 埋戻しまでを $2 \sim 3$ 日程度で終わらせるこ とも可能である。

\section{5-1.5) 埋戻し}

後述する測量, 観察, 試料採取・試験を実施し た後, トレンチを埋め戻して，用地を原状に復旧 する。その際には，十分に埋戻し土を転圧し，必 要に応じ，掘削した液状化層を砕石に置き換える などして，再液状化を防ぐ対策を行う。調查終了 後, 地権者立会のもと用地の復旧状況を確認す る。なお, 農地の場合は, 表層の耕作土と耕作土 以外の土砂は分別しておき，土砂を埋戻した後に 耕作土を均して農地を復旧する。

\section{5-2) 測量}

トレンチの形状，地盤高，周辺の地形，土地境 界，地物，基準点，噴砂，砂脈などの位置を測量 によって把握し，平板測量図を作成する。

液状化トレンチ調查では，トレンチを実施した 場所の過去の土地利用や古地図との対比が重要で ある。そのため, 古地図等により把握した旧河道 や埋め立てられた池, 沼などの位置を可能な限り 測量図に対応させる。また，確認できた噴砂や砂 脈の位置を測量図に正確に記入する。なお，測量 眓には，今後動く可能性が低い基準点を入れてお くことが望ましい。

\section{6) 観察}

地層区分を行い，地層境界の位置をスケッチ図 に示す。磁, 堆積構造, 炭化物, 植物·動物遺体, 砂脈，地層の削剥，生物攪乱，重機による整地の 跡を含む人工攪乱層, 溝, 坑, 水路, 埋積物など を確認し，形状をスケッチ図に表現する。単層ご との粒度, 層厚, 級化やラミナなどの堆積構造の
有無，ラミナの変形の有無，礫層の場合は礫種・ 磁径・ 円磨度・風化度・基質を記載する。上述の うち人工摚乱層は，一般にブルドーザーやバック ホウなどの重機か人力により整地されたものであ る。ブルドーザーによる整地では，土砂を押し出 した際に粘土やシルトがロール状にまるまり，ト レンチ壁面で $10 \sim 15 \mathrm{~cm}$ くらいの円形ないし楕 円形の構造となってみられる。また，バックホウ や人力による整地では, シルトや粘土の塊が偽礫 状に含まれることが多い。これらのことから，ロー ル状の構造やシルトおよび粘土の偽礫に着目する と，人工摚乱層と自然堆積層との識別が容易にな る。スケッチは縮尺 20 分の 1 を基本とし, 液状 化跡が小さく, より詳細なスケッチが必要な場合 は 10 分の 1 にするなど，適宜縮尺を変える。年 代を示す可能性のある空き缶，プラスチック片な どの人工物，考古遺物，貝，植物遺体，腐植層な どを採取し，それらの採取位置を記載して保管す る。また，調査の各段階を記録した写真を撮影す るとともに，壁面の状況を撮影する。全景を撮影 するとともに，グリッドごとに写真を撮影し，壁 面全体をモザイク状に貼りあわせるとよい。

\section{7）地層の剥ぎ取り転写}

トレンチ壁面が液状化しやすい砂層主体である 場合，砂が容易に崩れて壁面を覆ってしまい，そ のすべての除去が困難であるため, 肉眼観察によ るスケッチや写真撮影では堆積構造や液状化とそ れにひき続く流動化による構造などの重要な構造 を十分に表現できないことが多い。そのような場 合は, 表面を覆う砂を含めて重要な構造を樹脂で 固め，地山側の地層を剥ぎ取り転写する。この剥 ぎ取り転写面を後でスケッチすることにより，現 地でのスケッチ時間を短縮することもできる。こ のように, 地層の剥ぎ取り転写は, 液状化層のト レンチ調査ではほぼ必須となる。

剥ぎ取り転写の方法はいくつかあるが，ここで は, トマック NS-10を用いる方法と, サンプレ ン WE およびハイセル SAC-100を用いる方法を 紹介する。用いる樹脂はいずれも比較的強度が高 く, 乾燥後の剥ぎ取り面の変形が小さいので利用 されることが多い。なお，両方法とも，遺跡発掘 
の際の壁面の保存の目的で奈良国立文化財研究所 埋蔵文化財センター（1980）が独自に開発して きた方法を液状化トレンチ調查用に一部改良した もの（風岡, 1989 など）である。剥ぎ取った地層 を標本にすると, 標本館などにおける展示のほか, アウトリーチイベントなどに出展して，広く関係 者を対象とした液状化層や液状化-流動化現象の 紹介や解説も可能となる。

\section{7-1）トマック NS-10 を使用する方法}

トマック NS-10 はウレタン系合成樹脂であり, 三恒商事株式会社がとり扱っている。トマック NS-10 を用いる利点は，乾燥後も柔軟性があり， 剥ぎ取った地層を軽く折りたためることである。 難点は，固結していないゆるい砂にトマック NS10 は塗りにくいことである。

\section{7-1.1）準備品}

トマック NS-10，寒冷紗，刷毛，洗面器など のトマック NS-10を入れる容器，ハサミ，カッ ター，霧吹きなどである。

\section{7-1.2）壁面整形}

地層を剥ぎ取る範囲を特定し，その範囲より数 $10 \mathrm{~cm}$ 広い範囲をねじり鎌や立ち鎌などを用いて 平滑にする。壁面から飛び出した植物根は剪定ば さみで切る。壁面が乾燥している場合は，霧吹き で少し水を吹きつけ，壁面を湿らせる。

\section{7-1.3) トマック NS-10 の塗布}

洗面器などの容器にトマック NS-10を入れ， 下方から塗布する。上下 $20 \sim 30 \mathrm{~cm}$ くらいの横 長の帯状に刷毛で塗り，全幅を塗布したら，直上 を同じく帯状に塗布し，繰り返していく。

\section{7-1.4）裏打ち}

トマック NS-10 が半乾燥したら，寒冷紗を裏 打ちする。裏打ちした寒冷紗にさらにトマック NS-10 塗る（図 6 ）。

\section{7-1.5）剥ぎ取り試料の分割}

剥ぎ取り面が畳大よりも大きいときは，その重 量や運搬の都合から，剥ぎ取り試料をカッターや 八サミを用いて分割する必要がある。その場合, 水糸の位置，分割部分の印，分割面の番号などを マジックで書き，写真撮影を行い，分割面の位置 関係が後からわかるようにする。分割しない場合

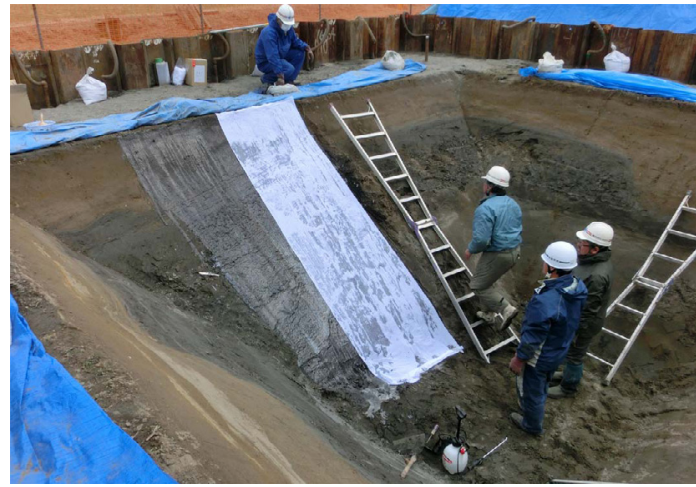

図 6 トマック NS-10を用いた剥ぎ取り標本作成中の 状況 (千葉県神崎町)

Fig. 6 View of relief peel specimen made with Tomack NS-10 as a grout material (Kozaki, Chiba Prefecture).

でも，剥ぎ取り面を剥がす前に露頭のどこから採 取したのかがわかるように，トレンチ面全体と剥 ぎ取り面の位置関係がわかるように写真撮影する。

\section{7-1.6) 剥ぎ取り}

トマック NS-10 が乾燥した後，塗布したトマッ ク NS-10にはりついた地層を剥がす。剥ぎ取っ た後のトレンチ断面を再度写真撮影する。乾燥に 要する時間はその時の気温により異なるが，夏季 で数時間，冬季で 1 日程度である。はりついた 礫が壁面に包含されとりにくい場合は，ハンマー やスコップで砂を掘り起こす。壁面から試料を剥 がす際に転写面から脱落した碩は保存し，脱落し た位置を記録し，乾燥後に接着剤ではりつける。 剥ぎ取り試料は乾燥後に軽く水洗いし，再乾燥さ せる（図 7 )。

\section{7-1.7）仕上げ}

必要に応じ，パネルにエポキシ樹脂系の接着剤 ではりつけるとともに，サンコール SK-50 や， 透明のラッカースプレーなどを吹きつけて潤色仕 上げにする。

\section{7-2）サンプレン WE とハイセル SAC-100 を} 使用する方法

地層固化用樹脂として使用するサンプレン WE は三洋化成工業株式会社が，螤打ち用樹脂である ハイセル SAC-100 は東邦化学工業株式会社がそ 


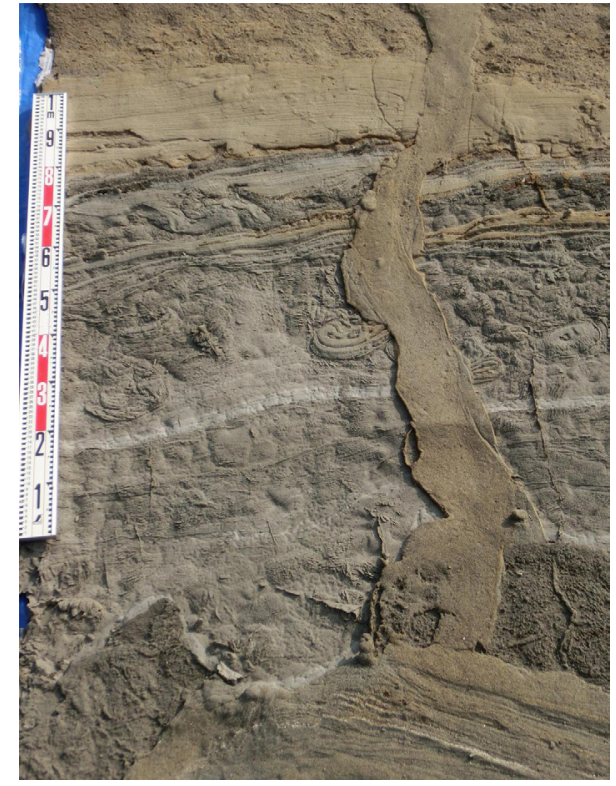

図 7 トマック NS-10を用いて採取された砂脈とその 周辺の地層剥ぎ取り標本例.

Fig. 7 Example of relief peel specimen comprising sand dike and soft sediments using Tomack NS-10.

れぞれとり扱っている。これらを使用する利点は, ごくゆるい地層でも剥ぎ取りが可能であることで ある。液状化-流動化が起こりやすい地層は，一 般にごくゆるく，透水性がよい場合が多い。この ため，使用する樹脂は親水性のものがよい。この 反面，親水性の樹脂は強度が弱い。このようなこ とから，まず親水性の樹脂を噴霧器で地層に染み 込ませ，乾いたのちに裏打ち用の強度の高い樹脂 をその上から塗布するとよい。この手法で行うと 液状化-流動化に伴う微妙な堆積構造の変形も再 現よく採取できる。

\section{7-2.1）準備品}

準備品はサンプレン WE，ハイセル SAC-100 のほかに, トマック NS-10 の場合と同様の準備 品, さらにアセトン, 噴霧器, ゴーグル, 有機溶 剂用ガスマスクなどを加える。

\section{7-2.2）壁面整形}

観察面を平面性よく整形する。なるべく凹凸が できないようにする。

\section{7-2.3) サンプレン WE $の$ 散布}

サンプレン WE をアセトンで薄めて噴霧器で 地層にたっぷり染み込ませる。サンプレン WE は発泡ウレタン系樹脂で, 原液は水あめのように 粘性が強く，そのままでは地層に染み込ませるこ とはできない。そこで，アセトン：サンプレン $\mathrm{WE}=4 \sim 8: 1$ となるように薄めて，地層に噴 霧する。噴霧の際は，勢いをつけすぎたり，樹脂 を多く噴霧しすぎたりすると観察面の地層を樹脂 とともに流下させてしまう。一方，噴霧する量が 少ないと，剥ぎ取り面にむらができてしまう。こ のため，観察面を作成する前のトレンチ断面にお いて，一度テストしてみるとよい。なお，噴霧器 は一度使用し，樹脂が乾くと目詰まりを起こすの で，スペアーが多くあったほうがよい。

\section{7-2.4) 裏打ち}

サンプレン WE を吹きかけた面は一般に 30 分 から 1 時間で乾く。乾いたことを確認したら，裏 打ち材の樹脂をその乾いた面に塗布する。この際, 強度を上げるため，寒冷紗や目開きが $5 \mathrm{~mm}$ $1 \mathrm{~cm}$ のメッシュをはりつける。メッシュをはり つけたのち，メッシュないし寒冷紗の上から再度 裏打ち材の樹脂を塗布し強度を上げる。裏打ち材 は，硬化する時間・作業時間・価格を考慮して決 める。ハイセル SAC-100 は, 水と混合させると 硬化時間が数分程度になるので，短時間に剥ぎ取 りを終えなくてはならない場合には便利である。 その代わりに，時間がたつと面が変形してくるの で，剥ぎ取り面の水洗い処理後早々に板などには りつける必要がある。

\section{7-2.5）剥ぎ取り試料の分割}

前述のトマック NS-10 を使用する方法に準じ て剥ぎ取り試料の分割を行う。

\section{7-2.6) 剥ぎ取り}

写真撮影後, それぞれの剥ぎ取り面を剥がして いく。その際，地層が剥ぎ取り面についているの かを確認しながら，慎重に行う。剥ぎ取った後の トレンチ断面を再度写真撮影する。

\section{7-2.7）仕上げ}

剥ぎ取り試料を保管・観察場所まで運搬した 後, 水洗いし, 余分な地層を洗い流す。この作業 
の最中に，さまざまな堆積構造が現れてくる。そ れらの構造を壊さない程度の水流で洗い流す。こ の際，決してブラシなどで洗い流さない。ブラシ でこするとブラシの跡がつき，堆積構造と区別が つかなくなってしまう。洗浄した剥ぎ取り面を日 陰干しにし, 乾燥したら洗浄面の保護と濡れ面の 再現のためにサンコールを塗り，これが乾けば完 成である。

\section{8）サンプリングと試験}

液状化トレンチでは，液状化-流動化した砂層 や砂脈を目視で確認できる。このため，液状化一 流動化層からサンプルを確実に採取することがで き, 液状化-流動化層や砂脈の分布と, 物性值お よび力学強度の分布との対応を直接的に把握する ことが可能となる。液状化層の液状化-流動化予 測に資するために，観察に加えて，サンプリング による室内試験や壁面を利用した原位置試験を実 施する。

\section{8-1）サンプリングと室内試験}

\section{8-1.1) 攪乱試料}

液状化一流動化層や液状化しなかった地層の粒 度組成, 密度, 比重, コンシステンシー等の物理 特性を把握するために，攪乱試料を採取して，物 理試験を行う。

試料は壁面をねじり鎌で整形した後，移植ごて やスプーンなどを用いて採取し，ビニール袋に入 れる。例えば，液状化層と液状化しなかった層の 境界を特定し，その境界を横断する測線に沿って 多数の試料を連続的に採取し，それぞれ物理試験 を実施すれば，その境界が示す物性值を把握する ことが可能となる。

\section{8-1.2) 不攪乱試料}

液状化層や液状化しなかった地層の力学特性を 把握するためには，不攪乱試料を採取して液状 化強度試験（繰返し非排水三軸試験：JGS05412009）などを行う。

不攪乱試料の採取方法としては，トレンチ壁面 に露出した液状化の対象層の上部に水平面を切り 出し, その面に塩ビ管，ステンレス管などのサン プラーをあて鉛直方向に押し込んで試料を採取す る。

\section{8-2）壁面を利用した原位置試験}

壁面を利用した原位置試験として，土壌硬度計 による測定，砂置換による土の密度試験（JIS A 1214-2001)，現場透水試験（JGS 1314-2003） があげられる。土壤硬度計による測定は，機動的 にかつ，容易に硬さを測定できる貫入式土䁃硬度 計（JGS 1441-2012）が有効的である。土䁃硬度 計を使用することにより，液状化一流動化による 緩みなどを計測值としてとらえることが可能とな る。あらかじめ $10 \mathrm{~cm}$ 間隔の格子を用意してお き，壁面に立てかけて格子ごとに測定を行うと効 率的に測定できる。

\section{9) 総合的な検討ととりまとめ}

壁面観察とスケッチ，写真，地層の剥ぎ取り転 写などをもとに，以下の点をとりまとめる。

(1)地層の細分とその新旧関係，とくに堆積間隙や 地質構造の違い，人工地層と自然地層の境界が どこであるかなどを明らかにする。

(2)地層の初生的な堆積構造と堆積後の変形構造の 違いを，砂などの構成粒子の配列や粘土薄層な ど本来水平に堆積すると仮定できる地層の形状 などから明らかにする。変形構造がみられる場 合には，地震による液状化-流動化変形と，地 すべり，埋立時のサンドポンプによる水流の影 響や重機による整地時の変形など別の原因によ るものが考えられるので, 総合的に変形の原因 を検討する。

(3)砂脈や堆積構造の消失した砂層の一部など，明 らかに液状化や流動化が生じた範囲と液状化し ていない部分の境界を明確にする。

(4)砂脈など流動化したことが明らかな層の粒度分 布，堆積構造を観察し，どの層からどのように 流動が進行しているかを明確にする。

(5)液状化一流動化した地層の切った・切られたの 関係や流動・変形の度合いの違いから, 液状化 が生じた時期と各地層の堆積時期との新旧関係 を明確にする。

また，現地調査終了後，各種採取試料の分析 結果や試験結果が出たのち，それらの結果を整 理して，以下の点などをとりまとめる。

(6)各地層に挟まる植物片, 泥炭, 原地性の貝など 
の年代測定結果や瓦，陶器片，空き缶，木杭， プラスチック製品などの遺物の同定から各地層 の年代を明らかにする。

(7)液状化が発生した年代を限定する。

8液状化した地層と液状化していない地層の粒度 組成やその他の物理計測值の違いなどから，液 状化が生じやすい特性を明らかにする。

(9)同じ地層中の液状化した部分と液状化していな い部分の粒度組成やその他の物理計測值の違い などから，液状化および流動化が進行していく ときに起こる諸過程を推定する。

\section{IV. ま と め}

液状化被害が懸念され，また人工地層の分布も 多い沖積低地において, 地下浅部の地質状況の把 握，液状化履歴の解明，液状化-流動化現象の実 態把握，液状化対策に資する具体的な方策を検討 するうえで，地面を掘削し地層を露出させて観察 するトレンチ掘削調査はもっとも直接的でわかり やすい方法である。本稿では，地下水面の高い低 地に適した短期間での効率的なトレンチ調査の手 法を提案し，その手順を示した。それらの要点 は，以下のようにまとめられる。

(1)トレンチ掘削に先立ち, 液状化跡の分布調査, 関連する既存資料の収集, 候補地現況確認, 事 前地盤調査（ボーリング調査，地下水位測定， 地下水の水質分析など）を実施する。

(2)トレンチ調查地点は地下水位が高いことが多 いので，シートパイルで囲ったのち，ウェル ポイント工により水位を低下させてから掘削 を行う。ウェルポイントの本数は, 必要排水量 とウェルポイントの揚水能力によって決められ る。このとき, 周辺地域での地下水位低下によ る影響と汲み上げた水の排水環境を考慮する必 要がある。

(3)トレンチの大きさは深さ $3 \sim 4 \mathrm{~m}$ までが現実 的であり, さらに深部の地質状況の把握には, 地層抜き取り装置を用いる方法などがある。地 下水面に達するところまでの浅いトレンチであ れば，時間や費用，用地面積をかなり抑えるこ とができる。
(4)トレンチ壁面観察では，噴砂，砂脈，陥没構造， 軟弱層の変形など液状化-流動化に伴う現象の ほか，それらと各地層との新旧関係，噴砂の供 給源などの観察を行う。また，液状化の生じた 層準, 液状化-流動化の発達過程, 液状化-流動 化による地層の強度変化などについて考察する。 (5)液状化-流動化構造など壁面にみられる変形構 造や堆積構造を詳細に記録し，保存するため, 地層の剥ぎ取り転写が必須である。剥ぎ取り標 本は，その後展示して関係者に広報することも 重要である。

(6)トレンチ調査では, 液状化した地層の年代測定 や分析・試験用の試料を直接採取できるほか, 土猿硬度計による地層の強度測定など，壁面を 利用した原位置試験を行うことができる。

\section{謝 辞}

トレンチ調查を実行するうえで榆井 久茨城大学名誉 教授には終始ご助言をいただいた。吉田 剛博士をはじ めとする千葉県環境研究センター地質環境研究室およ び小松原环，宮地良典，小松原純子各氏ほか産業技術 総合研究所平野地質研究グループの皆様にはトレンチ 調查現場での議論に加わっていただいた。日本建設機 械商事株式会社には, ウェルポイントの図をご提供い ただいた。 2 名の査読者と担当編集委員の方の指摘に より，本稿は大幅に改善された。以上の皆様に厚く感 謝申し上げる。震災で亡くなられた皆様のご冥福, 負 傷された皆様の回復・ご多幸, そして被災された地域 の復興を祈ります。

\section{文献}

Bastin, S.H., Bassett, K., Quigley, M.C., Maurer, B., Green, R.A., Bradley, B. and Jacobson, D. (2016): Late Holocene liquefaction at site of contemporary liquefaction during the 2010-2011 Canterbury Earthquake sequence, New Zealand. Bulletin of the Seismological Society of America, 106, 881-903.

Bezerra, F.H.R., da Fonseca, V.P., Vita-Finzi, C., LimaFilho, F.P. and Saadi, A. (2005): Liquefactioninduced structures in Quaternary alluvial gravels and gravelly sediments, NE Brazil. Engineering Geology, 76, 191-208.

土質工学会 (1987)：土と基礎実用数式・図表の解説 (第 1 回改訂版)。土質基礎工学ライブラリー 7 . [Japanese Society of Soil Mechanics and Foundation Engineering (1987): Explanation of Practical 
Formulas and Charts of Soil Mechanics and Foundation Engineering. Soil Mechanics and Foundation Engineering Library, 7 (Tsuchi To Kiso Jitsuyo Sushiki Zuhyo No Kaisetsu. Doshitsu Kiso Kogaku Raiburari 7). (in Japanese)*]

原口 強 - 島崎邦彦 - 小島圭二 - 北村精男 - 中田 高 · 松岡裕美 (1998)：地層抜取り装置による軟弱地盤に おける定方位連続地層採取方法. 土と基礎, $46(2)$, 24-26. [Haraguchi, T., Shimazaki, K., Kojima, K., Kitamura, A., Nakata, T. and Matsuoka, H. (1998): A new sampling method of unconsolidated sediments by long geo-slicer. Soil Mechanics and Foundation Engineering, 46 (2), 24-26. (in Japanese) ]

堀口万吉（1986）: 埼玉県北部でみられる古代の噴砂に ついて. 歴史地震， 2，9-14. [Horiguchi, M. (1986): Ancient jetted sands observed in the northern area of Saitama Prefecture. Historical Earthquakes, 2, 9-14. (in Japanese)*]

地盤工学会 (1991): 根切り工事と地下水：調查・設計 から施工まで. 丸善出版. [Japanese Geotechnical Society (1991): Pit Excavation Works and Groundwater (Nekiri Koji To Chikasui). Maruzen Shuppan. (in Japanese)*]

風岡 修 (1989): 地層のはぎ取り転写の導入とその有 効性について. 千葉県環境地質研究，20，49-52.

[Kazaoka, O. (1989): Large relief relief-peel method. Bulletin of Environmental Geology, Chiba, 20, 49-52. (in Japanese with English abstract) ]

風岡 修·楠田 隆・香村一夫 ·榆井 久. 佐藤賢司 . 原 雄 - 古野邦雄 - 香川 淳 - 森崎正昭 (1994) : 液 状化-流動化のメカニズムとその実態. 日本地質学会 第 101 年総会 · 討論会 講演要旨, 125-126. [Kazaoka, O., Kusuda, K., Kamura, K., Nirei, H., Satoh, K., Hara, Y., Furuno, K., Kagawa, A. and Morisaki, M. (1994): The process of liquefaction-fluidization at earthquake. Abstracts, the 101st Spring Meeting of the Geological Society of Japan, 125-126. (in Japanese)]

風岡 修 - 佐藤光男 - 楠田 隆 - 香村一夫 - 風戸孝之 香川 淳・森崎正昭・佐藤賢司・古野邦雄 - 酒井 豊・ 加藤晶子 - 榆井 久 (2000): 局所的な表層地質の違 いが液状化-流動化に与える影響一東京湾岸埋立地の 例一. 第 10 回環境地質学シンポジウム論文集，3338. [ Kazaoka, O., Sato, M., Kusuda, T., Kamura, K., Kazato, T., Kagawa, A., Morisaki, M., Satoh, K., Furuno, K., Sakai, Y., Kato, A. and Nirei, H. (2000): Liquefaction-fluidization on the boundary between artificial loose sand and soft mud-Reclaimed land around Tokyo Bay-. Proceedings of the 10th Symposium on Geo-Environments and Geo-Technics, 2000, 33-38. (in Japanese with English abstract) ]

風岡 修 - 佐藤光男 - 風戸孝之 - 楠田 隆 - 古野邦雄 香村一夫・佐藤賢司 - 原 雄 - 酒井 豊 - 笠原 豊 . 仁平雅子 - 加藤晶子 - 香川 淳 - 榆井 久 (2002): 1987 年千葉県東方沖地震時に見られた地波現象発生 地点での地層の状態. 第 12 回環境地質学シンポジウ ム・地質環境国際シンポジウム論文集，247-252.
[Kazaoka, O., Sato, M., Kazato, T., Kusuda, T., Furuno, K., Kamura, K., Satoh, K., Hara, Y., Sakai, Y., Kasahara, Y., Nihei, N., Kato, A., Kagawa, A. and Nirei, H. (2002): Geological condition on jinami phenomena, wavy ground transformation, by liquefaction-fluidization at 1987 east off Chiba Prefecture Earthquake. Proceedings of the 12th Symposium on Geo-Environments and Geo-Technics and International Symposium for Geological Environment 2002, 247-252. (in Japanese with English abstract)] 風岡 修・榆井 久. 香村一夫・楠田 隆・ 三田村宗 樹 (2003): 液状化・流動化. アーバンクボタ, 40, 1-65. [Kazaoka, O., Nirei, H., Kamura, K., Kusuda, T. and Mitamura, M. (2003): Liquefaction and fluidization. Urban Kubota, 40, 1-65. (in Japanese)*] 小松原 环·宮地良典・水野清秀・風岡 修·齋藤 勝· 細矢卓志 (2014) : 液状化・流動化層のトレンチ調査. 大地震による複合的地質災害に関する調査・研究報 告書，地質調查総合センター速報，66，273-288.

[Komatsubara, T., Miyachi, Y., Mizuno, K., Kazaoka, O., Saitou, M. and Hosoya, T. (2014): Trenching survey of liquefaction-fluidization layers. Reports of Research and Investigation on Multiple Hazards Caused by Huge Earthquakes, GSJ Interim Report, 66, 273-288. (in Japanese with English abstract) ]

三谷 豊 (2006): 千葉県北部の中部更新統に見出され た地震起源の液状化 - 流動化現象. 地球科学, 60 , 241-252. [Mitani, Y. (2006): Earthquake-induced liquefaction and fluidization in middle Pleistocene in the northern area of Chiba Prefecture, Japan. Earth Science (Chikyu Kagaku), 60, 241-252. (in Japanese with English abstract)]

Mugnier, J.L., Huyghe, P., Gajurel, A.P., Upreti, B.N. and Jouanne, F. (2011): Seismites in the Kathmandu basin and seismic hazard in central Himalaya. Tectonophysics, 509, 33-49.

奈良国立文化財研究所埋蔵文化財センター (1980)：層 位・遺跡断面等の剥ぎ取り転写法. 埋蔵文化財ニュー ス, 28, 1-8. [Center for Archaeological Operations, Nara National Research Institute for Cultural Properties (1980): Method for making peel specimen off stratigraphical and archaeological sediment sections. CAO NEWS, 28, 1-8. (in Japanese)*]

日本道路協会（1999）：道路土工 仮設構造物工指針. [Japan Road Association (1999): Road Earthwork - Temporary Structure Works Guideline (Doro Doko, Kasetsu Kozobutsuko Shishin). (in Japanese)*]

Nirei, H., Kusuda, T., Suzuki, K., Kamura, K., Furuno, K., Hara, Y., Satoh, K. and Kazaoka, O. (1990): The 1987 East Off Chiba Prefecture Earthquake and its hazard. Memoirs of the Geological Society of Japan, 35, 31-46.

沼田淳紀 - 森 伸一郎 - 陶野郁雄 - 遠藤邦彦 (1999): 液状化で生じた砂脈と噴砂に関する一考察. 土木学 会論文集，638，311-324. [Numata，A., Mori, S., Tohno, I. and Endo, K. (1999): A study on sand 
dikes and sand boils caused by liquefaction. Journal of Japan Society of Civil Engineers, 683, 311324. (in Japanese with English abstract) ]

Obermeier, S.F. (1996): Use of liquefaction-induced features for paleoseismic analysis-An overview of how seismic liquefaction features can be distinguished from other features and how their regional distribution and properties of source sediment can be used to infer the location and strength of Holocene paleo-earthquakes. Engineering Geology, 44, 1-76.

岡田篤正（1990）：トレンチ法による活断層調査の現状 と展望. 米倉伸之・岡田篤正・森山昭雄編 : 変動地 形とテクトニクス．古今書院，18-44. [Okada, A. (1990): Current status and issues of active fault study by trenching survey. in Tectonic Geomorphology and Tectonics (Hendo Chikei To Tekutonikusu) edited by Yonekura, N., Okada, A. and Moriyama, A., Kokon Shoin, 18-44. (in Japanese)*]

大塚富男 - 高浜信行 - 中里裕臣・野村 哲 (1997): 群馬県烏川中流域のテフラ中にみられる液状化現象 とその意義. 第四紀研究， 36，123-136. [Otsuka, T., Takahama, N., Nakazato, H. and Nomura, S. (1997): Ancient liquefactions and their significance in the late Quaternary tephra layers in the Karasu river valley, Gunma Prefecture, Japan. Quaternary Research (Daiyonki-kenkyu), 36, 123-136. (in Japanese with English abstract) ]

Reddy, D.V., Nagabhushanam, P., Kumar, D., Sukhja, B.S., Thomas, P.J., Pandey, A.K., Sahoo, R.N., Prasad, G.V.R. and Datta, K. (2009): The great 1950 Assam Earthquake revisited: Field evidences of liquefaction and search for paleoseismic events. Tectonophysics, 474, 463-472.

寒川 旭 (1992): 地震考古学 遺跡が語る地震の歴史. 中央公論社. [Sangawa, A. (1992): Earthquakearchaeology-History of the Earthquake Documented by Archaeological Sites- (Jishin Kokogaku). Chuou Koronsha. (in Japanese)*]

寒川 旭 (1999): 遺跡にみられる液状化現象の痕跡。 地学雑誌，108，391-398. [Sangawa, A. (1999): Paleoliquefaction features at archaeological sites in Japan. Journal of Geography (Chigaku Zasshi), 108, 391-398. (in Japanese with English abstract) ] 重野聖之・鈴木喜之・福間 哲 - 風岡 修 - 吉田 剛 七山 太 (2015): 浅層地下の大型定方位試料採取法 のツールとしての改良型 ACE ライナー：液状化-流 動化調査工事への応用. GSJ 地質ニュース，4，101106. [Shigeno, K., Suzuki, Y., Fukuma, T., Kazaoka, O., Yoshida, T. and Nanayama, F. (2015): The improved ACE liner as a tool of large constant orientation sampling method from shallow underground: An application for liquidizing-fluidizing study. GSJ Chishitsu News, 4, 101-106. (in Japanese)]

下川浩一 ·衣笠善博 - 佃 栄吉 - 水野清秀 ·井村隆介 (1994)：北海道奥尻島及び北檜山町における液状化
堆積物のトレンチ調査結果. 地震予知連絡会会報, 52, 29-33. [Shimokawa, K., Kinugasa, Y., Tsukuda, A., Mizuno, K. and Imura, R. (1994): Trenching study of the liquefied sediments in the Okushiri Island and Kitahiyama Town. Report of the Coordinating Committee for Earthquake Prediction, $\mathbf{5 2}$ 29-33. (in Japanese) ]

下総台地研究グループ (2010): 茨城県南東部の更新統 で確認された液状化-側方流動の痕跡と小断層群の 形成. 地球科学, 64, 149-158. [Shimousa Daichi Research Group (2010): Liquefaction-lateral flow features and minor faults in Pleistocene in the southeastern area of Ibaraki Prefecture, Japan. Earth Science (Chikyu Kagaku), 64, 149-158. (in Japanese with English abstract)]

Takada, K. and Atwater, B.F. (2004): Evidence for liquefaction identified in peeled slices of Holocene deposits along the lower Columbia River, Washington. Bulletin of the Seismological Society of America, 94, 550-575.

高浜信行 · 卜部厚志 - 寺崎裕助 - 大塚富男 - Budi Brahmantyo - 江口友子 - 中山俊道 - 荒木繁雄 - 川上貞雄 田村浩司（1998）：新潟県における歴史地震の液状 化跡一その 1. 新潟大学積雪地域災害研究センター研 究年報, 20, 81-104. [Takahama, N., Urabe, A., Terasaki, Y., Otsuka, T., Brahmantyo, B., Eguchi, T., Nakayama, T., Araki, S., Kawakami, S. and Tamura, K. (1998): Liquefactions of historical earthquake in the Niigata Prefecture, Japan-Part1. Annual Report of the Research Institute for Hazards in Snowy Areas, Niigata University, 20, 81-104. (in Japanese with English abstract)]

陶野郁雄 (1986): 液状化現象からみた砂質堆積物の 物理的. 堆積学的特徵. 地質学論集, 27, 15-42.

[Tohno, I. (1986): Physical and sedimentological properties of liquefiable sandy deposits produced by the strong earthquake in Japan. Memoirs of the Geological Society of Japan, 27, 15-42. (in Japanese with English abstract)]

Tuttle, M.P., Lafferty III, R.H., Cande, R.F. and Sierzchula, M.C. (2011): Impact of earthquake-induced liquefaction and related ground failure on a Mississippian archeological site in the New Madrid seismic zone, central USA. Quaternary International, 242, 126-137.

ウェルポイント協会 (2007) : ウェルポイント工法便覧. 理工図書. [Well-point Association (2007): Handbook of the Well-point Method (Well-point Koho Binran). Riko Tosho. (in Japanese)*]

山崎晴雄 ·佃 栄吉 ·水野清秀 (1984): 活断層のトレ ンチ掘削調査. 応用地質, 25, 141-145. [Yamazaki, H., Tsukuda, E. and Mizuno, K. (1984): Excavation survey of the active fault. Journal of the Japan Society of Engineering Geology, 25, 141-145. (in Japanese) ]

* Title etc. translated by K.M. 